\title{
Relationship Between Parental Support And Learning Motivation
}

\author{
Nurlina $^{1 *}$, Amirullah ${ }^{2}$ \\ Departemen Mental Health Nursinf, Stikes Panrita Husada Bulukumba, Indonesia ${ }^{1}$ \\ Departemen Surgical Medical Nursing , Stikes Panrita Husada Bulukumba ,Indonesia²
}

Corresponding Autor : nurlinapanrita@gmail.com*

\begin{abstract}
Based on information obtained from some students in 38 public elementary schools, Gattareng, researchers found that they lacked motivation and support from their parents, so their children were also less focused on studying at home and more playing with their friends. Learning motivation is one of the factors that influence student success in teaching and learning in school. This is because each student has a different motivation between students with one another. Parental support is a very important role and is very needed by children who can support the academic achievement of children in school, one form of parental support is to give attention and help in the problems in the field of education faced by children. This study aims to determine the relationship of parental support with learning motivation in class IV and V. This type of research is a quantitative analytic study with a cross-sectional approach. With a large sample of 45 respondents. The sampling technique using total sampling method. Data analysis using a chi-square test with p-value (0.05).The results showed that respondents who said that the support of parents in the support category were 25 respondents $(55.6 \%)$ and those who did not support 20 respondents (44.4\%). While learning motivation in the high category was 22 respondents (48.9\%) and learning motivation in the low category was 23 respondents (51.1\%). This means that there is a significant relationship between the relationship of parental support with motivation to learn $(p=0.001)$ at the 38th elementary school. The conclusion that there is a significant relationship between the relationship of parental support with motivation to learn in class IV and V in elementary school 38 Gattareng Bulukumba district. Suggestions that parents provide support to children to be motivated to learn and get high learning achievement.
\end{abstract}

Keywords: Parental Support, Learning, Motivation

\section{INTRODUCTION}

Education is one aspect of determining the progress of a country, including in Indonesia. It is no exaggeration if the founders of the Indonesian people put lofty ideals in the opening of the 1945 constitution which states that the formation of the government of the State of Indonesia is in the framework of "Protecting all Indonesians and throughout Indonesia and to spill the blood of the nation and to advance public welfare, educate the nation's life" because that, the success of education is one of the goals of this nation's education. So that education is needed that is planned, directed, and sustainable (Humaerah, 2014). 


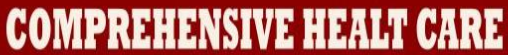

The role of the nurse is the behavior expected by others to someone in accordance with the position in the system, which can be influenced by social conditions both from the nurse profession and from outside the nursing profession which is constant. Where the role of nurses as providers of nursing care is this role carried out by taking into account the conditions of basic human needs needed through the provision of services so that they can be planned and carried out appropriate actions according to the level of basic human needs, then the level of development can be evaluated. Advocate The role in assisting families in interpreting various other information, especially in taking the consent given can also play a role in defending and protecting their rights. Educator This role is done in increasing the level of knowledge so that behavior changes occur after being given education. This role coordinator is carried out by directing, planning, and coordinating so that it can be directed and in accordance with human needs. This role collaborator is carried out because the nurse works through the team and seeks to identify the services needed including discussion or exchange of opinions in determining the next form of service. Consultation This role is as a place for consultation on problems or appropriate actions to be given. Researchers or reformers This role can be done by planning, Nation, aims to develop the potential of students to become human beings who believe and be devoted to a God who is almighty, noble, healthy, knowledgeable, capable, creative, independent and become citizens of a democratic and responsible ". But in reality what happens in the field is just the opposite. Education in Indonesia has not been able to realize the functions and objectives of education optimally (Humaerah, 2014).

Education in Indonesia still shows low quality. The statement was proven, among others, by UNESCO (2000) data on the ranking of the Human Development Index, Human Development Index, which is the composition of the rankings of educational attainment, health, and head income which shows that the human development index in Indonesia is declining. Among 174 countries in the world, Indonesia ranks 102nd (1996), 99th (1997), 105th (1998) and 109th (1999). Further facts are shown by Balitbang (2003) data that of 146,052 elementary schools in Indonesia, only eight schools received world recognition in the Primary Years Program (PYP) category. Motivation to learn can be influenced from oneself (intrinsic), which is based on the need for learning, and from outside oneself (extrinsic) that is motivation that comes from the family (especially parents), as the child's closest environment. Intrinsic 
learning motivation needs to be grown to instill in children that learning is a necessity, not just an obligation. If that awareness has arisen, then the child will carry out learning activities with his own awareness, without the need for coercion from any party, or only at the time of the test, while to grow intrinsic learning in children can do so by giving rewards to each development that the child has achieved in their learning activities, listen to the child's complaints about the learning activities they do, provide penalties that contain lessons, pay attention to the things that children do when they learn, and take time to accompany children to learn (Dhiean, 2006, quoted in Fajriyah, 2012).

Learning motivation is one of the factors that influence student success in teaching and learning in school. This is because each student has a different motivation between students with one another. Therefore, teachers and parents have a role in providing motivation to learn to students, especially parents' support for the success of children's education. With the support of parents, especially the attention of parents in children's education, is expected to provide the spirit of children's learning in order to achieve an ideal or achievement (Fajriyah, 2012). In learning, parents have a significant role in children's learning success. Parents are the first and foremost people responsible for the survival and education of their children. Therefore, as a parent must be able to help and support all the efforts made by their children and can provide informal education to help the growth and development of the child and to attend or continue education in formal education programs in schools (Hasbullah, 2001, quoted in Fajriyah , 2012).

Parental support when students learn can support student motivation in learning. A harmonious family relationship between father, mother and children is a dream for every student, the child will ask parents if they encounter things that they do not yet know, otherwise parents always ask about the development of their learning at any time. A pleasant atmosphere in the family, can also affect children's learning motivation because children can learn calmly so that in the end it will also succeed in the teaching and learning process (Astuti, 2007 quoted in Fajriyah, 2012). The results of research conducted by Fajriyah (2012) show that there is a very significant positive relationship between parental support and student motivation in SD Negeri Laweyan Surakarta. The effective contribution of parental support variables to student motivation is $53.1 \%$. The support of parents of SD Negeri 1 Laweyan Surakarta Elementary School students is classified as very high with the average and motivation of learning of SD Negeri 1 Laweyan Surakarta Elementary School students is high. From the data obtained in the 
state elementary school area 38 gattareng Bulukumba regency in 2015 obtained data that the total number of students was 211 divided into 6 classes. First class has 48 people, second class has 40 people, third class has 42 people, fourth class has 20 people, fifth class has 25 people and sixth class has 36 people.

Based on information obtained from some elementary school students in 38 gattareng, researchers found that they lacked motivation and support from their parents, so their children were also less focused on studying at home and more playing with their friends. Not all parents have the same attention to their children's education, some have good attention, for example providing the learning facilities that children need, and accompanying their children to learn by giving intensive guidance, some are being indifferent, meaning that children's development is left entirely to the teacher and the child alone. In addition, most parents of students are also still unable to provide learning facilities, such as additional textbooks. Based on the report cards obtained that students get an average report card score of 75.1, 75.5, there are only a few students who get report cards values of 93.6, 92.5 and 90.5. Based on the explanation above, the researcher is interested in conducting research on "The Relationship between Parents' Support and Children's Learning Motivation in 38 Public Elementary Schools gattareng".

\section{MATERIAL AND METHODS}

The design of this study is an analytic survey using a cross sectional approach because it measures research variables in the same time or moment (Notoatmodjo, 2010). What is assessed is the relationship of parental support with motivation to learn in elementary school children in 38 gattareng. Population is the overall source of data needed in a study (Saryono and Anggraeni, 2013). The population in this study were 38 elementary school students in grade IV and V, as many as 45 students. The sample is part of the number and characteristics possessed by the population (Sugiyono, 2012). total sampling also called saturated sampling is a sampling technique when all members of the population are used as samples (Sugiyono, 2012).

Instrument of this research can be in the form of: questionnaire (list of questions), observation forms, other forms relating to recording data and so on (Notoadmodjo, 2010). Data collection used an independent variable in the form of a questionnaire consisting of several questions using a Likerts scale approach that contains several statements with correct answers score 1: If it has never been done, 2: If rarely done, 3: If often done, 4: If always conducted. and for data collection The dependent variable in this 
study is in the form of a questionnaire sheet using a Likerts scale containing statements with correct answers score 1: If it has never been done, 2: If rarely done, 3: If often done, 4: If always done . Data analysis is shown to answer the research objectives and test the research hypotheses. In the statistical test used is the chi square test if it meets the requirements contained in the data obtained. If it does not meet the requirements, then an alternative test is used namely the Kolmogrov test and cell merging

\section{RESULTS}

Table 1. Distribution of Characteristics of Respondents by Age, Gender, Parental Education

\begin{tabular}{|c|c|c|}
\hline Characteristics of Respondents & $\mathrm{n}$ & Percentage \% \\
\hline Age & 1 & 2.2 \\
\hline 7 Year & 3 & 6.7 \\
\hline 8 Year & 15 & 33.3 \\
\hline 9 Year & 17 & 37.8 \\
\hline 10 Year & 7 & 15.6 \\
\hline 11 Year & 2 & 4.4 \\
\hline \multicolumn{3}{|l|}{12 Year } \\
\hline \multicolumn{3}{|l|}{ Gender } \\
\hline Male & 23 & 51.1 \\
\hline Female & 22 & 48,9 \\
\hline \multicolumn{3}{|l|}{ Class } \\
\hline Class IV & 18 & 40.0 \\
\hline Class V & 27 & 60.0 \\
\hline Amount & 45 & 100,0 \\
\hline
\end{tabular}

The table above shows the 45 respondents based on the characteristics of Age, Gender, Parental Education. Most respondents aged 10 years are 17 people (37.8\%), 8 years old are 3 people (6.7\%), 9-year-old respondents are 15 people (33.3\%), 7-year-old respondents are 1 person $(2.2 \%)$, respondents aged 11 years amounted to 7 people (15.6\%), and respondents aged 12 years were 2 people (4.4\%) Most respondents were male as many as 23 people (51.1\%). In the educational characteristics of class IV respondents were 18 people (40.0\%). And in class $\mathrm{V}$ as many as 27 people $(60.0 \%)$.

Table 2. Frequency Distribution of Respondents Based on Parental Support

\begin{tabular}{lcc}
\hline Parental support & n & Percentage (\%) \\
\hline Support & 25 & 55.6 \\
Does not support & 20 & 44.4 \\
\hline Amount & 45 & 100.0
\end{tabular}

Based on data from the Table shows that respondents who get the support of parents in the category of support as many as 25 people (55.6\%) While those who do not support as many as 20 people (44.4\%). 
Table 3 Distribution of Respondent Frequencies Based on Learning Motivation

\begin{tabular}{lcc}
\hline Motivation to learn & $\mathbf{n}$ & Percentage (\%) \\
\hline High & 22 & 48.9 \\
Low & 23 & 51.1 \\
\hline Amount & 45 & 100.0 \\
\hline
\end{tabular}

Based on data from the Table shows that respondents who have high learning motivation are 22 people (48.9\%) while low motivation to learn is 23 people (51.1\%).

Table 4. Frequency Distribution of Relationships Between Parental Support and Learning Motivation

\begin{tabular}{|c|c|c|c|c|c|c|c|}
\hline \multirow[t]{3}{*}{ Parental Support } & \multicolumn{4}{|c|}{ Motivation to learn } & \multirow{2}{*}{\multicolumn{2}{|c|}{ Amount }} & \multirow{2}{*}{$P$ value } \\
\hline & \multicolumn{2}{|c|}{ High } & \multicolumn{2}{|c|}{ Low } & & & \\
\hline & $\mathrm{n}$ & $\%$ & $\mathrm{~N}$ & $\%$ & $\mathrm{~N}$ & $\%$ & \\
\hline Support & 18 & 40,2 & 7 & 15.5 & 25 & 55.7 & 0,001 \\
\hline Does Not Support & 4 & 8,8 & 16 & 35.5 & 20 & 44.3 & \\
\hline Amount & 22 & 49 & 23 & 51 & 45 & $100 \%$ & \\
\hline
\end{tabular}

Based on the above table of 25 respondents, who said that support from parents who support with high learning motivation as many as 18 people $(40.2 \%)$ while low motivation to learn as many as 7 people (15.5\%). And from 20 respondents, who said that the support of parents who did not support with high learning motivation were 4 people (8.8\%), while low motivation to learn was 16 people (35.5\%). Based on the results of the chi-square test, it was found that there was a relationship between parental support and learning motivation in grade IV and V children in 38 elementary schools in the district of Bulukumba with a value of $p=0.001$ $<\alpha=0.05$.

\section{DISCUSSION}

The results of this study showed that most respondents in the support category were 23 (51.1\%) respondents while the support of parents in the non-supportive category was 22 (48.9\%) respondents. This study is in line with research conducted by Wahyuni (2009) that from 57 respondents it can be seen the amount of support from parents who support as many as 45 (78.8\%) respondents and who do not support as many as 12 (54.4\%) respondents. Parental support is an important component in children's education. This requires direct contact that can be realized in the form of parental support for their children. Parents who provide support to their children in learning will be able to increase the enthusiasm of children so that they can study hard, study hard and not be easily discouraged if they have difficulties in learning (Tan, 2013).

This is also reinforced by Nasution's research (2005) in Wahyuni (2009) which says that parents have the greatest role in the family, such roles include motivators, 
facilitators and mediators. As a motivator parents must always provide motivation or encouragement to their children to seek knowledge. As a facilitator, parents must provide facilities, fulfill family / child needs in the form of clothing, food and including educational needs. As a mediator, parents must act as mediators (mediators / intermediaries) in community family relationships, especially with schools. Parents who care about their child's progress will always try to provide the best for their children, providing the desired facilities for children to achieve good children's performance. This is in line with the opinion of Hasbullah (in Tan et.al 2013) which states that parents are the first and foremost people responsible for the survival and education of their children.

Researchers assume that good parental support is full support for children who are informative in the form of giving advice, direction and consideration of how someone should do. As well as support for assessments that provide feedback on the results or achievements and awards for the efforts made by children, because that way the child will get used to and eager to learn. From the results of this study it can be seen that respondents who learn motivation with a high category are 23 respondents $(51.1 \%)$, while in the low category are 22 respondents (48.9\%). This is in line with the research of Ratnasari (2014) which shows that from 135 respondents it can be known that the number of high learning motivations is 70 (93.3\%) of respondents and low learning motivation of 55 (88.7\%) respondents. Indie in Wahyuni (2009) states that motivation has an important role in the learning process. Students who are low motivation will experience many problems in learning, for example students seem slow to do tasks related to learning activities, being lazy, easily discouraged, play truant, doing school work, and indifferent to everything related to school activities. This condition has a very bad impact on the success of learning.

Uno in tan.et.al (2010) states that learning motivation is the internal and external encouragement of students who are learning and to make changes in behavior so that it will foster student enthusiasm in doing the marei learning process both in school and in general. This is reinforced by the opinion of Shah (2012) which states that the lack or lack of motivation both internal and external will cause lack of enthusiasm of students in doing learning process materials both at school and at home because in students who consider easy subjects, students who are not sympathetic and enthusiastic about the teacher who teaches and the weak fighting power of students. Researchers assume that 
good learning motivation can be done through self-effort that is by preparing for learning such as learning before lessons begin, preparing books and learning tools. Motivation to learn can be done such as always paying attention to the explanation of the teacher with enthusiasm, reading, discussing, trying diligently in learning and studying the material that has been taught and encouragement from the environment. The results of the study conducted obtained the results of hypothesis testing using the chi-square test showed a p value of 0.001 . This means that there is a relationship between parental support and motivation to learn in class IV and V in elementary school 38 gattareng.

This study is in line with research conducted by Tan et.al (2013) the relationship between parent support and children's learning motivation at school age in Kawangkoan Kalawat state primary school which says that there is a relationship where a p value of 0.0002 is obtained which means there is a relationship which is between parent support and learning motivation in children. This is consistent with the theory put forward by Gunarsa cited in Mindo (2008) that the family environment is one of the important factors that can influence children's learning achievement. Families that produce highachieving children are families that encourage and support the learning process that their children experience, have a great interest and concern for children's education, and prepare children for the lessons they will receive at school. Efforts to increase parental support must continue. One effort to increase children's learning motivation is the attention of parents in the development of children's learning both at school and at home. Parents are required to provide understanding and encourage it and help wherever possible difficulties experienced by children, if the child experiences enthusiasm.

Motivation can be increased by involving family or parents, because education is not only the responsibility of the government, but also the responsibility of the family and society. The child's attitude towards school will be influenced by the attitude of the parents, so that parents' trust in the school is needed to replace their duties while in school. The other role of the family is to teach the values and behavior taught at school (Indie, 2009). Researchers assume that good parental support is both physical and psychological support that is needed by children in stimulating learning. From the results of the study showed that there are still parents who support the learning motivation of children but low as many as 7 people. This is because there are still other 
factors that influence learning motivation, among others, lack of interest in learning, lack of motivation to children so that children do not study well. In addition there are 4 respondents who although their parents do not support but they still have high motivation, this can be caused by the ideals and desires of the students themselves so that they remain enthusiastic and motivated even with low support from parents.

\section{CONCLUSIONS}

There is a relationship between the relationship of parents with learning motivation in class IV and V in elementary schools in 38 gattareng Bulukumba Regency with $\mathrm{p}=$ $0.021<\alpha=0.05$. 2 . It is suggested to the school to hold regular student parent meetings with the school to urge parents of the importance of their role and support for children's learning achievement.

\section{REFERENCES}

Aeni, Nur, Yeni \& Supratiningsih, Endang, 2012, Hubungan orang tua dengan motivasi belajar pada siswa akhwat kelas VIII di mts misbahunnur kota cimahi, Jurnal ilmiah kesehatan, Bandung : Fakultas psikologi universitas islam.

Andarmoyo, Sulistyo, 2012. Keperawatan keluarga, Konsep Teori, proses dan praktik keperawatan, Edisi pertama. Yogyakarta : Graha ilmu.

B, Hamzah, H, Dr \& M,Pd, Uno, 2010, Teori Motivasi Dan Pengukurannya, Edisi pertama, cetakan keenam. Jakarta : PT. Bumi Aksara.

Djaali, H, Dr, Prof, 2009. Psikologi Pendidikan, Edisi pertama, cetakan Keempat. Jakarta : PT. Bumi Aksara.

Hidayah, Nur, Fajriyah, 2012, Hubungan Antara Dukungan Orang Tua Dengan Motivasi Belajar Pada Siswa SD Negeri Bumi I Laweyan Surakarta, Jurnal IImiah Kesehatan, Surakarta : Fakultas Psikologi Universitas Muhammadiyah.

Jaya, 2012, Hubungan antara dukungan orang tua dengan motivasi belajar, Jurnal Kesehatan IImiah, Surakatra : Fakultas Kesehatan Universitas Muhammadiyah. 


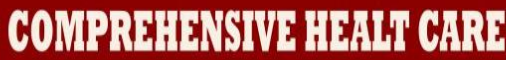

Jahja, Yudrik, 2011. Psikologi Perkembangan, Edisi pertama. Jakarta : PT. kharisma putra utama. Kencana prenadamedia.

Kep, Sp, M.kep, Wahyuni, Sri \& M, Saam zulfan, Dr, Prof, 2013, Psikologi keperawatan, Jakarta: RajaGrafindo persada.

Kes, M, Sunaryo, Drs, 2013, Psikologi Untuk Keperawatan, buku kedokteran, Edisi kedua. Jakarta : EGC.

Lestari, Sri, 2012. Psikologi Keluarga, Edisi pertama. Jakarta : PT. Kharisma putra utama, Kencana prenada media.

L, Jhonson, R, Leny, 2010. Keperawatan keluarga. Yogyakarta : Nuha medika

M, S.Ag, Khodijah, Nyayu,Dr, 2014. Psikologi Pendidikan, Jakarta : PT. RajaGrafindo persada

Sugiyono, Dr, Prof, 2012, Metode Penelitian Kuantitatif, Kualitatif, Dan R\&D, Bandung : Alfabeta

S, kep. Titik, Lestari, 2015, kumpulan Teori Untuk Kajian Pustaka Penelitian Kesehatan. Yogyakarta : PT. Nuha medika.

Tan, Haediyani, jane,. Ismanto, Yudi, Amatus \& Babakal, Abraham, 2012, Hubungan Antara Hubungan Dukungan Orang Tua Dengan Motivasi Belajar Pada Anak Usia Sekolah, Jurnal IImiah Kesehatan, Manado : Fakultas Kedokteran Universitas Sam Ratulangi

Wahyuni, Rimba, susi, Eska, 2009, Hubungan Antara Dukungan Orang Tua Dengan Motivasi Belajar Anak Pada Usia Sekolah Di SD Petampon, jurnal IImiah Kesehatan, Semarang : Fakultas Keperawatan Dan Kesehatan Universitas Muhammadiyah 